\title{
Growth, development and distribution of the euphausiids Thysanoessa raschi (M. Sars) and Thysanoessa inermis (Krøyer) in the southeastern Bering Sea
}

SHARON L. SMITH

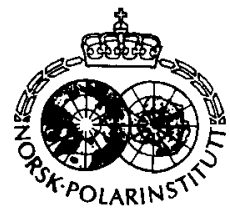

Smith, S. L. 1991: Growth, development and distribution of the euphausiids Thysanoessa raschi (M. Sars) and Thysanoessa inermis (Krøyer) in the southeastern Bering Sea. Pp. 461-478 in Sakshaug, E., Hopkins, C. C. E. \& Øritsland, N. A. (eds.): Proceedings of the Pro Mare Symposium on Polar Marine Ecology, Trondheim, 12-16 May 1990. Polar Research 10(2).

The distribution and abundance of the euphausiids Thysanoessa raschi and Thysanoessa inermis in the shelf waters of the southeastern Bering Sea were investigated during spring and summer of 1980 and 1981 . Experiments were conducted during the study to describe the reproduction, growth and development of these species. $T$. inermis was the dominant euphausiid species observed over the outer shelf region; it began spawning in early April while $T$. raschi dominated the euphausiids over the middle shelf and began spawning in mid or late May. The seasonal progression in spawning followed the seasonal development of temperature; however, spawning did not begin earlier in 1981 which was a warmer year than 1980 . Average egg production of $T$. raschi ranged from $3.4 \%$ to $3.8 \%$ dry body weight of the female per day during the first three days after capture. Secondary production estimates for $T$. raschi females ranged from $4.2 \%$ to $5.2 \%$ dry body weight per day in 1980 and $5.9 \%$ to $6.0 \%$ dry body weight per day in 1981 . A sharp decline in the abundance of adolescent and adult euphausiids over the middle shelf during the spring bloom period when food appeared to be abundant suggests that predation by diving birds, pollack, Tanner crabs, whales and seals effectively controls the euphausiid population.

Sharon L. Smith, Oceanographic and Atmospheric Sciences Division. Brookhaven National Laboratory, Upton. New York 11973, USA (revised January 1991).

\section{Introduction}

Arctic, subarctic and boreal continental shelves often have relatively small euphausiids of the genus Thysanoessa prominently in their food webs (Macdonald 1928; Einarsson 1945; Brinton 1962; Ponomareva 1966; Geiger et al. 1968; Minoda \& Marumo 1974; Soboleva 1974, 1975; Fukuchi 1977; Lindley \& Williams 1980; Hopkins et al. 1984; Vidal \& Smith 1986). In the Arctic Ocean, euphausiids were collected primarily over the shelf and slope, and not from various ice islands used for sampling the deep basins in the 1950s and 1960's (Geiger et al. 1968). The euphausiids captured in the Arctic Ocean were predominantly Thysanoessa inermis (Krøyer) and Thysanoessa raschi (M. Sars), and they were especially abundant in the Barents, Beaufort, and Chukchi Seas. The East Siberian and Laptev Seas did not contain these species, nor did the Canadian Archipelago (Geiger et al. 1968). In the Bering Sea, which feeds the Chukchi Sea via the Bering Strait, $T$. inermis was collected along the shelf edge, whereas $T$. raschi was located in shallow shelf waters (Minoda \& Marumo 1974). T. raschi was associated with colder, less saline coastal waters of the Bering Sea (Fukuchi 1977), a phenomenon also observed in the Barents Sea where the eggs and nauplii of $T$. inermis and $T$. raschi were collected in water masses of quite distinct temperature and salinity characteristics (Timofeyev 1987).

Since these two species generally co-occur (Ponomareva 1966; Geiger et al. 1968; Mauchline \& Fisher 1969), many studies compare various characteristics of the species. Most investigations agree that $T$. inermis breeds before $T$. raschi in spring (Ponomareva 1966; Minoda \& Marumo 1974; Soboleva 1974; Lindley 1980; Falk-Petersen et al. 1982; Hopkins et al. 1984, 1985), and that eggs are released in the upper water column anywhere from the upper $10 \mathrm{~m}$ (Davis 1982) to the 
upper $25 \mathrm{~m}$ (Ponomareva 1966). Detailed studies of the life cycles of these euphausiids and their life history adaptations have been undertaken in Balsfjorden. T. raschi overwinters partially on its stored lipid, but it also seems to rely upon omnivorous feeding throughout the year. It reproduces later and for a more prolonged period than T. inermis (Hopkins et al. 1984, 1985), suggesting that spawning in $T$, raschi is tied to ambient food supplies. Estimates of specific growth rates of these two species vary between 1.2 and $8.6 \%$ per day (Lindley \& Williams 1980; Falk-Petersen et al. 1982; Hopkins et al. 1984; Vidal \& Smith 1986).

Mortality is high in the younger stages (Ponomareva 1966; Berkes 1977; Lindley \& Williams 1980) but difficult to assess in older individuals. Older and larger individuals that reach the surface earliest to spawn in spring are seldom captured later in the year, but whether they are preyed upon or die from other causes is unknown (Ponomareva 1966). Several species of baleen whale (blue, fin, sei and humpback) are known to feed upon $T$. inermis especially (Nemoto 1957), birds prey upon $T$. raschi (Schneider et al. 1986), and ringed seals in the Bering Sea have stomachs full of euphausiids (Ponomareva 1966). There are suggestions that older stages aggregate (Macdonald 1928; Ponomareva 1966; Soboleva 1974; Zelikman et al. 1978, 1980) and that fish such as cod select larger individuals from such aggregations (Zelikman et al. 1978). Changes in the geographical distribution of $T$. inermis and $T$. raschi in the Barents Sea caused euphausiids to become a less important component in the diet of cod when the center of abundance of $T$. raschi, the cod's usual prey, shifted to the east of the cod's feeding grounds in the Barents Sea (Soboleva 1975). Aggregation is difficult to quantify because of the swimming capabilities, and hence net avoidance, of larger individuals.

In 1980 we began a two year investigation of the zooplankton of the southeastern Bering Sea in a multi-year, multidisciplinary experiment known as PROBES (Processes and Resources of the Bering Sea Shelf). The shelf of the southeastern Bering Sea is divided into three regions, the inner. middle, and outer shelf, separated from each other by frontal zones. The communities of the outer shelf and slope are dominated by largebodied copepods such as Neocalanus cristatus, Neocalanus plumchrus, and Eucalanus bungii, characteristic of the central North Pacific Ocean and the deep basin of the Bering Sea (Cooney \& Coyle 1982; Smith \& Vidal 1984, 1986; Vidal \& Smith 1986). Annual secondary production on the outer shelf is governed by wind events in spring which inject slope water carrying large numbers of copepods into the shelf environment where phytoplankton are plentiful (Smith \& Vidal 1986; Vidal \& Smith 1986). Growth rates of the copepods are high, and large body size is achieved (approximately twice that of individuals in the slope water population) before the population declines due to predation (Vidal \& Smith 1986; Smith \& Vidal 1986). Euphausiids comprised an average of $27 \%$ of the total zooplanktonic biomass over the outer shelf and slope in April and $15 \%$ in May 1980 (Vidal \& Smith 1986). In the middle shelf habitat, isolated from exchange with the outer shelf and deep basins of the Bering Sea by a strong salinity front, euphausiids comprised an average of $88 \%$ of total biomass in April and $68 \%$ in May 1980 (Vidal \& Smith 1986). The dominance of the euphausiids in the middle shelf region, their biomass, and their production in 1980 and 1981 comprise the topic of this study.

\section{Methods}

The PROBES section consisted of 19 stations spaced $22 \mathrm{~km}$ apart and included the slope and inner shelf regions. Stratified samples of zooplankton were collected at five standard stations using a multiple opening/closing net system (MOCNESS) (Wiebe et al. 1976) fitted with 149 $\mu \mathrm{m}$ mesh nets and towed at 2 knots (Fig. 1). Stations 12 and 16 are in the middle shelf region. Sampling intervals were $1200-600,600-300$, $300-120,120-80,80-60,60-40,40-20$, and $20-0 \mathrm{~m}$ at deep stations; the intervals were modified for shallower bottom depths. Collections were split at sea; $50 \%$ were preserved in $5 \%$ neutral formalin and returned to the laboratory for analysis of species composition and age-structure. Euphausiids were identified using descriptions of Einarsson (1945) and Boden et al. (1955). Adults were individuals with fully developed secondary sexual characteristics; adolescents were individuals with all luminescent organs, five pair of setose pleopods, spines on telson equivalent in number to adults, but with reproductive organs and characteristics not fully developed; furcilia were any individuals not attributable to either the adolescent or calyptopis categories. Approxi- 


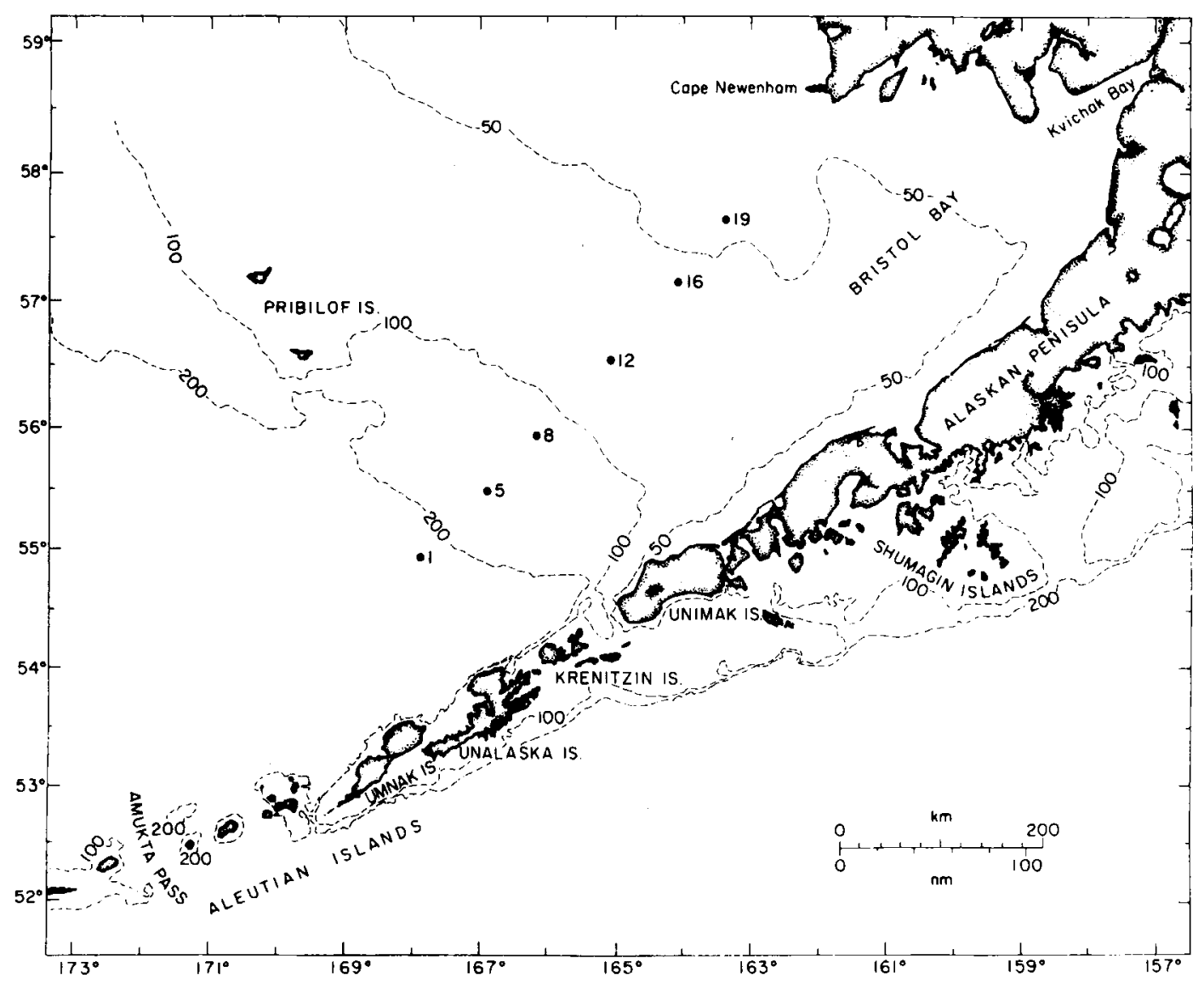

Fig. 1. The southeastern Bering Sea showing the PROBES transect extending from slope waters (Station 1) to the inner shelf region (Station 19). Data in this study were collected at Stations 12 and 16 . Frontal zones occur at approximately the 50, 100 and $200 \mathrm{~m}$ isobaths.

mately once every three weeks we occupied a 24hour station at one of the locations shown in Fig. 1 , except station 19. Full sets of stratified tows were collected five times during 24-hour periods, and each net tow was preceded and followed by a CTD cast. Water motion over the southeastern Bering Sea is driven primarily by tides, with slow northeastward drift of $1-5 \mathrm{~cm} \mathrm{~s}^{-1}$ (Coachman 1986). The lack of strong advective motion allowed us to sample a single section repeatedly and to feel reasonably confident that censuses were being taken of the same populations. The repeated, stratified tows covering day, night and crepuscular conditions revealed quite clearly the potential underestimate of the abundance of older euphausiids that would result from daytime sampling (Fig. 2A). The numbers of adolescent and adult $T$. raschi and $T$. inermis captured at night were on average seven times the numbers captured in the day at any given depth of any station (Fig. 2A). The abundance of nauplii and calyptopis stages, however, did not show such a dramatic day versus night discrepancy, although their numbers captured at night were 1.5 times their numbers captured by day (Fig. 2B). The most likely explanation of the observation is avoidance of the net by larger individuals in daytime; however, because sampling did not extend absolutely to the bottom, we cannot rule out the possibility that larger stages aggregate within the lower few meters of the water column during daytime. If this were the case, then their migration into the water column at night would be the explanation of the discrepancy in numbers captured during daytime and at night. Regardless of the explanation, accurate abundances of euphausiids can 

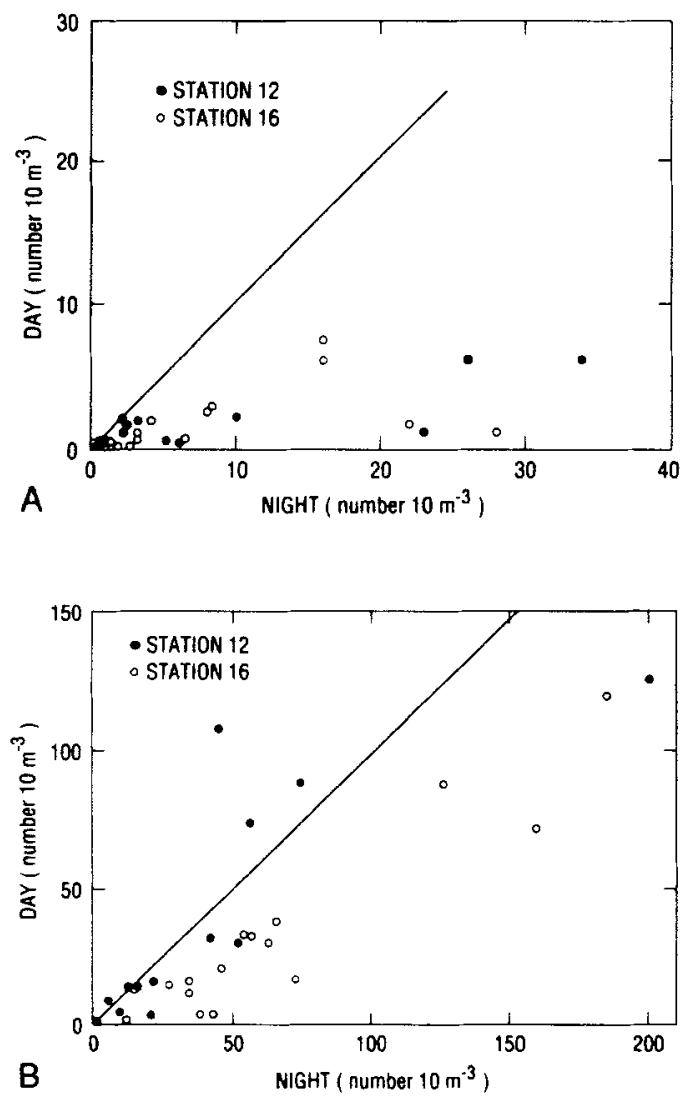

Fig. 2. Comparison of day and night abundances of cuphausiids collected in stratified net sampling. A. Total numbers of adolescent and adult euphausiids captured in paired day and night tows of a MOCNESS. B. Total numbers of nauplii and calyptopis stages of euphausiids captured in paired day and night tows of a MOCNESS.

only be estimated by night-time sampling, and in high latitudes in summer this is often a difficult or impossible task. We have not attempted any assessment or description of vertical migration due to this clear sampling bias. Complete listings of abundance data collected during PROBES have been published (Smith et al. 1982, 1983).

Dry weights of specimens preserved in $5 \%$ formalin-seawater solution were measured using a Cahn model 26 electrobalance. Individuals, or groups of individuals, were sorted from a sample, rinsed in distilled water, transferred to preweighed aluminium boats, and dried in a drying oven at 40 to $50^{\circ} \mathrm{C}$ for at least 24 hours before dry weight determinations. Females used in egg production experiments were rinsed in distilled water at the end of the experiment, placed in aluminum boats, dried at sea, returned to the laboratory in desiccant, and weighed ashore after an additional 24 hours in a drying oven. A mean loss of $40 \%$ of dry weight because of preservation has been assumed (Vidal \& Smith 1986).

The females used to measure rates of egg production were captured with a $0.5 \mathrm{~m}$ ring fitted with $500 \mu \mathrm{m}$ mesh net, towed at $0.5 \mathrm{kt}$ for $10-20$ minutes at a depth selected to coincide with the highest near-surface acoustic backscatter registered by the ship's PDR. The collection was diluted in a bucket of surface seawater, and individual females were captured with a wide-bore pipette and transferred to 1-liter, double containers. The inner container had a mesh bottom which allowed eggs to fall through, thereby preventing reingestion by the female during incubation. The containers were incubated at 5.3 or $7^{\circ} \mathrm{C}$, depending on ambient sea surface temperature, and in darkness for 24 hours. At the end of 24 hours the female was transferred to another double-walled container filled with fresh surface seawater. The water the female was removed from was gently poured through $25 \mu \mathrm{m}$ mesh which retained the eggs. The container was washed once with filtered seawater and that water was also poured through the $25 \mu \mathrm{m}$ mesh. Eggs resting on the mesh were counted immediately. Sometimes the eggs were backwashed with fil tered seawater into vials and preserved in $5 \%$ neutral formalin. Most often, eggs were backwashed into vials of filtered seawater and then incubated at 5.3 or $7^{\circ} \mathrm{C}$ in darkness. A census was taken every 24 hours for numbers of eggs hatching, and then numbers of subsequent naupliar and calyptopis stages which appeared. Halfway through the 1981 study, daily censuses were abandoned and duplicate vials, usually about six vials containing 20 eggs each, were set up using the eggs from known females. The vials were incubated as before, but every 24 hours one vial was sacrificed and preserved in 5\% formalin. Enumeration of various naupliar and calyptopis stages was done later in the laboratory. Mortality was much higher in the vials examined (handled) each day than in the vials which were untouched until preservation. These observations gave us stage durations of young $T$. raschi and the daily secondary production accounted for by egg release. Females were transferred into fresh seawater each day until they no longer laid eggs.

Weight-specific growth rates of older stages of 
Table 1. Average number of euphausiids (adults $\mathrm{m}^{-2}$ ) in the southeastern Bering Sea, 1980.

\begin{tabular}{lrrrr}
\hline & \multicolumn{4}{c}{ Stations } \\
& 5 & 8 & 12 & 16 \\
\hline Thysanoessa inermis & 78 & 144 & 104 & 8 \\
Thysanoessa raschi & 0 & 17 & 131 & 88 \\
\hline
\end{tabular}

$T$. raschi and $T$. inermis were computed from the equation

$$
G=\frac{\left(\ln W_{2}-\ln W_{1}\right)}{\left(t_{2}-t_{1}\right)} \times 100
$$

where $\mathrm{G}$ is the weight-specific growth rate in \% per day, and $W_{2}$ and $W_{1}$ are mean dry weights at time 2 and time 1 in days.

Temperature was obtained at all stations using a Neil Brown Mark III CTD surrounded by a small rosette sampler. The data were processed according to Coachman \& Charnell (1979) and reported by Niebauer et al. (1982a, b).

\section{Results}

Average abundance of adult Thysanoessa raschi and Thysanoessa inermis show that $T$. inermis is located primarily over the outer shelf with extension to Station 12 in the middle shelf, whereas $T$. raschi is generally not present in the outer shelf, but is abundant over the middle shelf (Table 1). No adults were captured at Station 19 over the inner shelf in 1980 , probably because sampling there was always conducted in daytime. The timing and location of euphausiid spawning can be derived from sections showing the abundance of naupliar stages (Fig. 3). Virtually no nauplii were in the waters of the PROBES line in late March and early April; the few observed were collected on 2 April. By mid-April, $50 \mathrm{~m}^{-3}$ were found between 20 and $40 \mathrm{~m}$ over the outer shelf. In early May, nauplii were most abundant around the middle front (Station 8, Fig. 1). In late May and early June, euphausiid nauplii were most abundant over the middle shelf (Stations 12 and 16). The seasonal progression in spawning by euphausiids, as indicated by naupliar abundance, follows the seasonal development of temperature (Fig. 4). Spawning began on the outer shelf four to six weeks prior to spawning on the middle shelf.
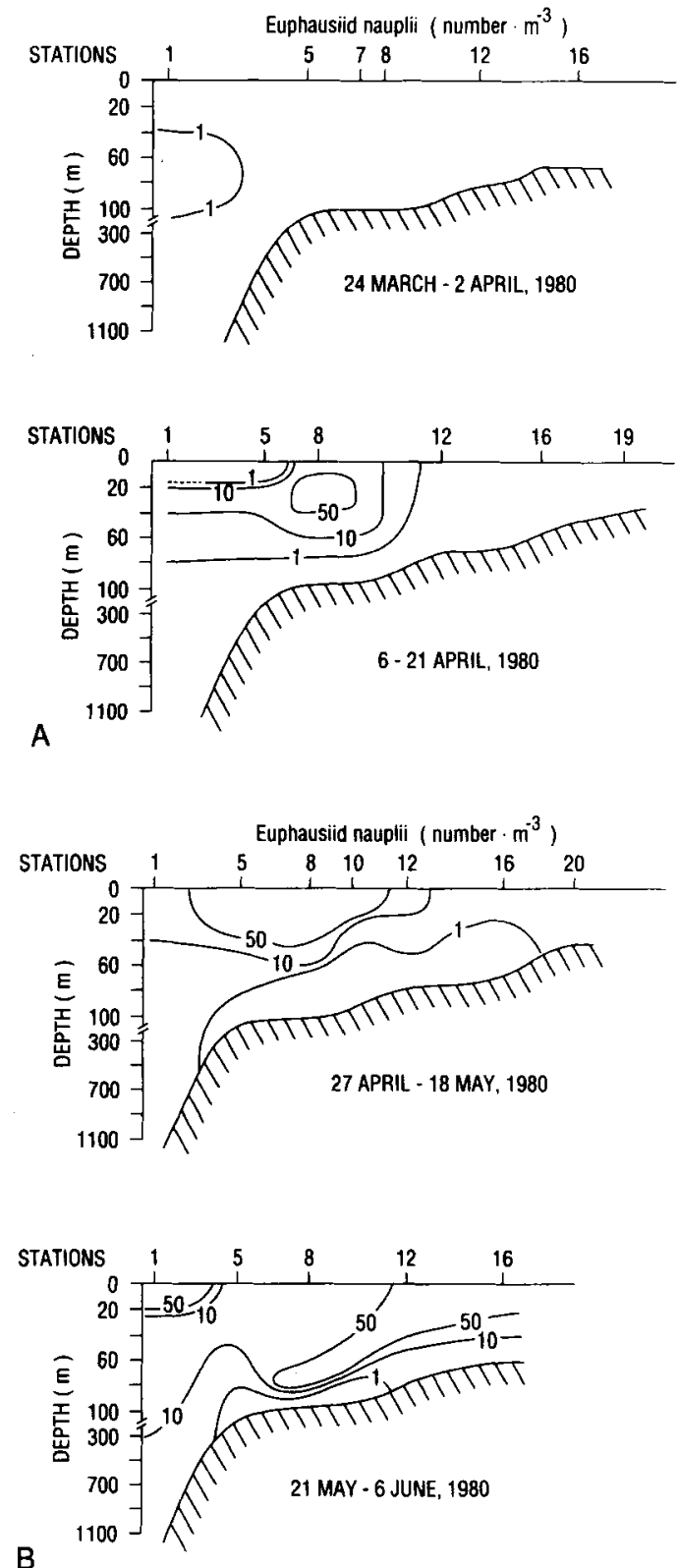

Fig. 3. Timing and location of euphausiid spawning determined by naupiiar abundance (number $\mathrm{m}^{-3}$ ). A. Distribution of nauplii of euphausiids along the PROBES section in early spring. March-April 1980. B. Distribution of nauplii of euphausiids along the PROBES section in late spring, May-June 1980.

In late March 1980, temperatures at Stations 12 and 16 were between 0 and $1^{\circ} \mathrm{C}$; by early June, surface temperatures had reached $4^{\circ} \mathrm{C}$ (Fig. 4). Temperatures over the outer shelf (Stations 5 and 


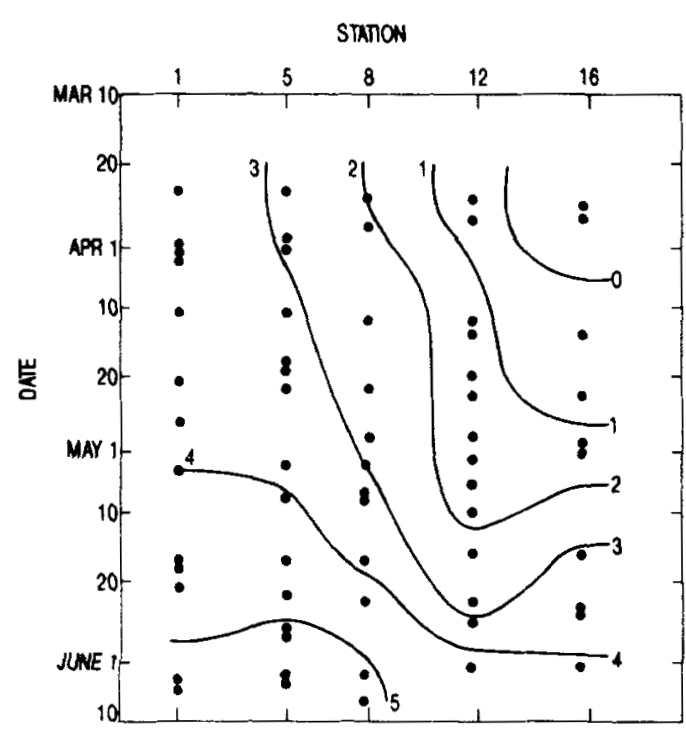

SEA SUAFACE TEMPERATURE $\left(0^{\circ} \mathrm{C}\right)$

Fig. 4. Changes in sea surface temperature with time along the PROBES section in 1980 .

8) were between 3 and $5^{\circ} \mathrm{C}$ in the March-June period (Fig. 4). The distribution of nauplii suggests that $T$. inermis of the outer shelf began reproducing in early April and continued through early May at least, whereas $T$. raschi over the middle shelf did not begin to spawn until mid or late May.

The distribution of calyptopis stages was consistent with that of nauplii. The calyptopes were present only at the oceanic station (Station 1, Fig. 1) in late March 1980, and by April they had reached considerable abundance there $\left(50 \mathrm{~m}^{-3}\right.$, Fig. 5). The large number of nauplii over the outer shelf (Stations 5 and 8, Fig. 1) in April 1980 had no counterpart in the calyptopis stages in April, suggesting that the young euphausiids (primarily $T$. inermis) over the outer shelf developed more or less as a cohort. The large concentration of nauplii over the outer shelf in April 1980 were seen in early May as large concentrations of calyptopis stages (Fig. 5). The overall progression in space and time from nauplius to calyptopis over the continental sheif of the southeastern Bering Sea suggests that $T$. inermis reproduced in April over the outer shelf, whereas $T$. raschi reproduced in May over the middle shelf.

During late April and the first half of May 1980 ,
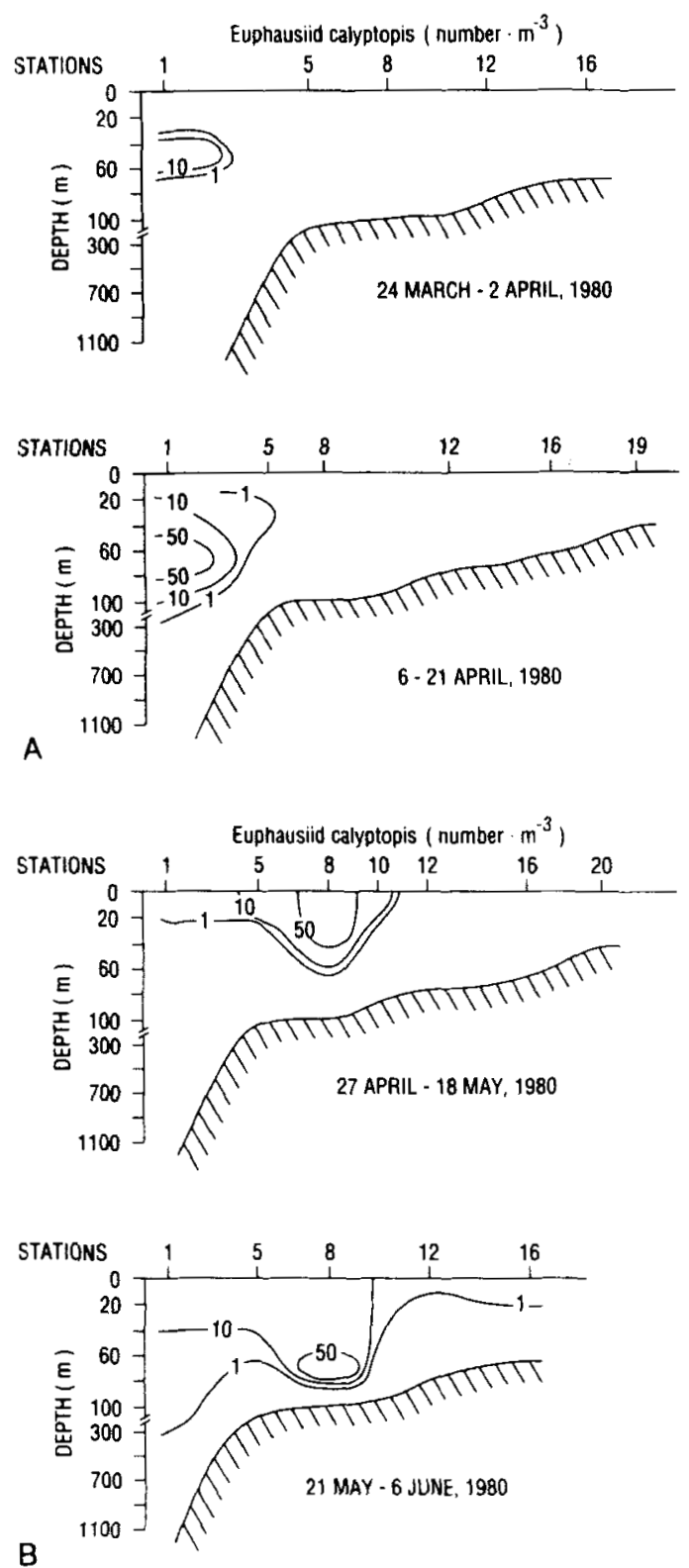

Fig. 5. Seasonal development of euphausiid populations in the southeastern Bering Sea indicated by calyptopis abundance. A Total numbers of calyptopis stages of all species of euphausiid across the shelf in early spring. March-April 1980. B. Total numbers of calyptopis stages of all species of euphausiid across the shelf in late spring. May-June 1980.

there were relatively few $T$. inermis over the middle shelf, the most abundant form being adolescents captured at Station 12. In late May and early June, we captured no $T$. inermis at Station 
16 and only a few adults at Station $12 . T$. raschi was always more abundant than $T$. inermis and was most abundant in late April and the first half of May as adults at Station 16 and as adolescents at Station 12. During late May and early June $1980, T$. raschi adults were equally abundant at Stations 12 and 16. At Station 12, the growth of $T$. raschi females and adolescents was such that samples which were 24 days apart generally did not overlap either in carapace length or in dry weight (Fig. 6). This suggests that essentially one cohort was growing up at this location at a specific growth rate of approximately $4.5 \%$ dry body weight per day. At Station 16 , growth by weight was such that samplings 23 days apart generally did not overlap, but carapace length did (Fig. 6) making carapace length by itself an insufficient measurement for describing and analyzing growth in $T$. raschi, in contrast to the suggestion of Mauchline \& Fisher (1969).

The two years, 1980 and 1981, that we studied the euphausiids of the Bering Sea were quite different. The first, 1980, was cold and stormy while 1981 was warmer and less stormy. The result of these conditions was evident in sea-surface temperatures (Figs. 4 and 7). In 1980, sea-surface temperatures over the middle shelf were less than $2^{\circ} \mathrm{C}$ from early April until mid-May, whereas in 1981 temperatures during the same time period were between 3 and $6^{\circ} \mathrm{C}$ (Figs. 4 and 7). By the end of the 1980 study (June 10), temperatures on the middle shelf had warmed to $4^{\circ} \mathrm{C}$, whereas at the same time in 1981 the temperature had reached $8^{\circ} \mathrm{C}$. Initial sea-surface temperatures were warmer in 1981, and the sea surface continued to warm at a faster rate in 1981 than during our study in 1980. Bottom temperatures over the middle shelf were almost identical to the surface temperatures and both were ca. $1^{\circ} \mathrm{C}$ below the ten-year mean in 1980 and $\mathrm{ca} .1^{\circ} \mathrm{C}$ above the mean in 1981 (Incze 1983). The biomass of euphausiids, however, was less in the warm year (Fig. 8), although biomass was increasing at the end of the field season in 1981. In May, for example, peak biomass was similar at Station 12 both years (ca. 150-200 $\mathrm{mg}$ dry weight $\mathrm{m}^{-2}$ ), but at Station 16 the peak in 1980 was $400 \mathrm{mg} \mathrm{m}^{-2}$ compared with only $150 \mathrm{mg} \mathrm{m}^{-2}$ in 1981 . It is tempting to speculate that the warmer temperatures in 1981 hastened development and reproduction. Numbers of nauplii captured at Station 16, however, were virtually identical both years (Table 2) during the periods in which the studies overlapped. At Sta-

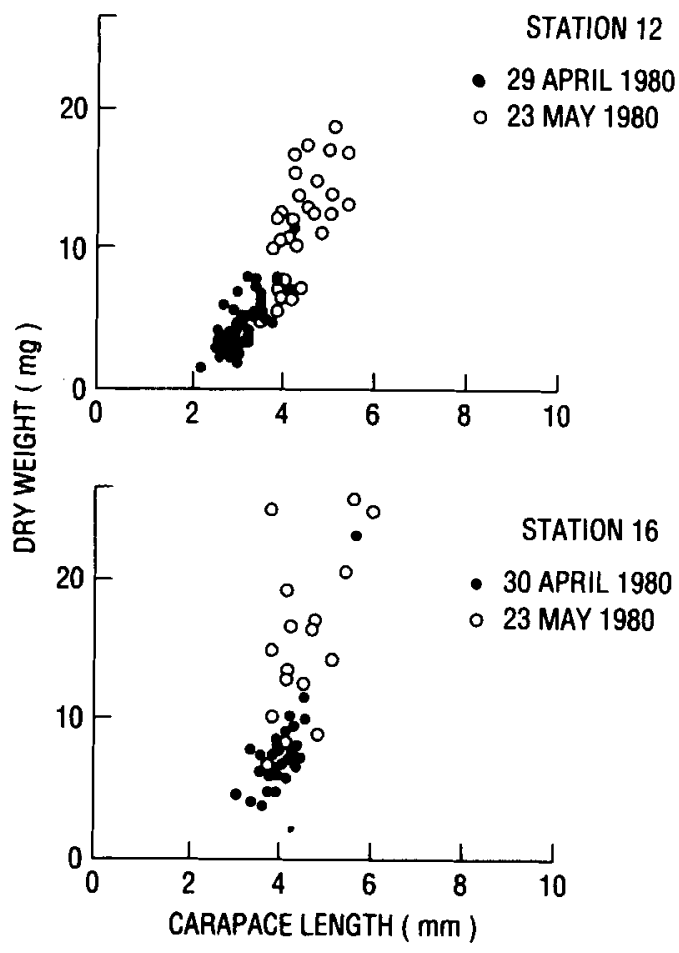

Fig. 6. Correlation of carapace length and dry weight of adult and adolescent females of $T$. raschi at Stations 12 and 16.

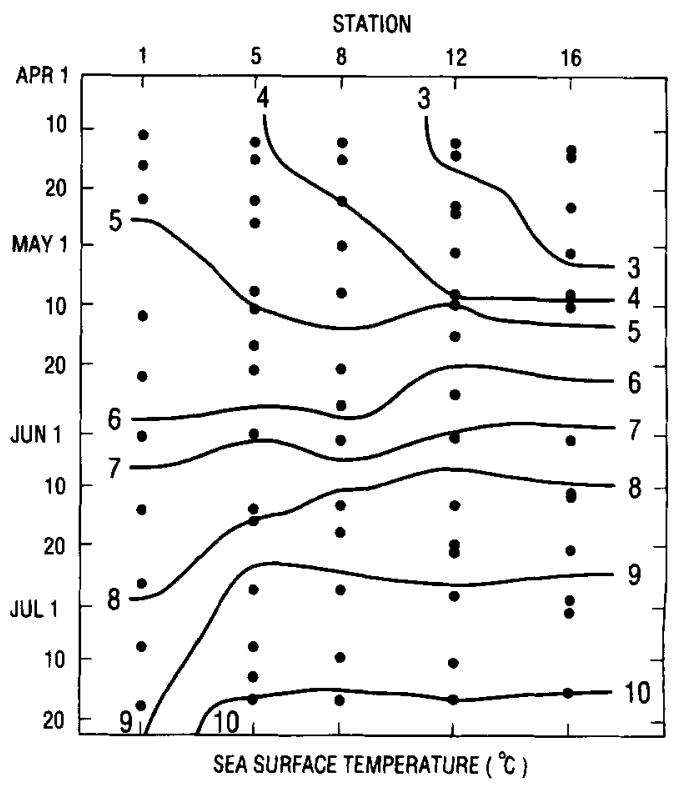

Fig. 7. Changes in sea surface temperature with time along the PROBES section in 1981 

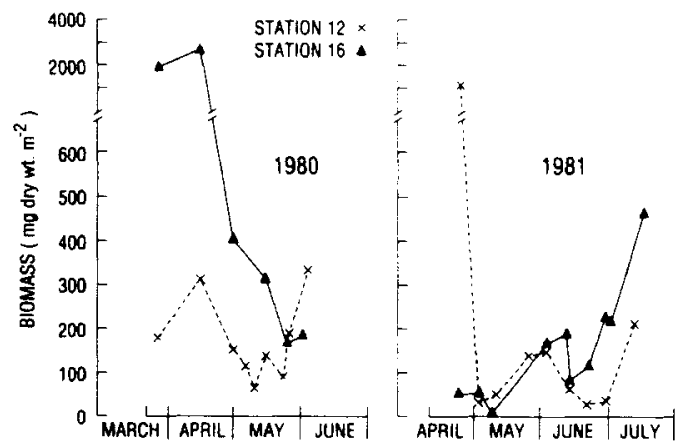

Fig. 8. Total biomass of euphausiids at Stations 12 and 16 in 1980 and 1981 .

tion 12 there were actually more nauplii in the water earlier during the cold year (1980, Table 2). Thus, warmer conditions did not induce earlier spawning, probably because the phytoplankton bloom also was not earlier in the warmer year (Smith \& Vidal 1986).

Individual size is a variable that might be affected by temperature. At Station 16, individuals of $T$. raschi were larger, in general, in the warmer year (Tables 3 and 4). In some cases, individuals were nearly twice the dry weight in 1981 on a given date as they had been in 1980 (adolescent female $T$. raschi, Tables 3 and 4). At Station 12, however, there was very little difference in size for this species between the two years. $T$. inermis
Table 2. Abundance of nauplii of euphausiids over the middle shelf of the Bering Sea.

\begin{tabular}{|c|c|c|c|}
\hline Location & Year & Date & Number $\mathrm{m}^{-2}$ \\
\hline \multirow[t]{6}{*}{ Station 16} & 1980 & $85^{*}$ & 8 \\
\hline & & 104 & 0 \\
\hline & & 121 & 7 \\
\hline & & 135 & 1099 \\
\hline & & 144 & 2107 \\
\hline & & 152 & 2373 \\
\hline \multirow[t]{8}{*}{ Station 16} & 1981 & 113 & 0 \\
\hline & & 122 & 6 \\
\hline & & 128 & 256 \\
\hline & & 144 & 1395 \\
\hline & & 153 & 2368 \\
\hline & & 162 & 1075 \\
\hline & & 172 & 3674 \\
\hline & & 180 & 4435 \\
\hline \multirow[t]{9}{*}{ Station 12} & 1980 & 87 & 8 \\
\hline & & 109 & 7 \\
\hline & & 119 & 193 \\
\hline & & 126 & 727 \\
\hline & & 130 & 1366 \\
\hline & & 136 & 3104 \\
\hline & & 143 & 919 \\
\hline & & 146 & 1358 \\
\hline & & 153 & 1346 \\
\hline \multirow[t]{9}{*}{ Station 12} & 1981 & 114 & 0 \\
\hline & & 122 & 0 \\
\hline & & 130 & 0 \\
\hline & & 145 & 1848 \\
\hline & & 153 & 308 \\
\hline & & 163 & 77 \\
\hline & & 171 & 539 \\
\hline & & 180 & 886 \\
\hline & & 193 & 7783 \\
\hline
\end{tabular}

-Date given in Julian days

Table 3. Weights of two species of euphausiids over the middle shelf of the Bering Sea in 1980 (mean dry weight per individual in $\mathrm{mg} \pm$ one standard deviation).

\begin{tabular}{|c|c|c|c|c|}
\hline Date & $\begin{array}{l}\text { Adolescent } \\
\text { Female }\end{array}$ & $\begin{array}{l}\text { Adolescent } \\
\text { Male }\end{array}$ & $\begin{array}{l}\text { Adult } \\
\text { Female }\end{array}$ & $\begin{array}{l}\text { Adult } \\
\text { Male }\end{array}$ \\
\hline \multicolumn{5}{|c|}{ Thysanoessa raschi } \\
\hline \multicolumn{5}{|c|}{ Station 16} \\
\hline $86^{*}$ & $1.96 \pm 0.47$ & - & $4.37 \pm 2.47$ & $9.01 \pm 4.40$ \\
\hline 104 & $2.55 \pm 0.15$ & - & - & $3.72 \pm 0.65$ \\
\hline 145 & $7.83 \pm 1.77$ & $9.84 \pm 1.11$ & $11.42 \pm 3.31$ & $7.72 \pm 2.65$ \\
\hline 153 & $7.16 \pm 1.38$ & - & $9.72 \pm 1.33$ & - \\
\hline \multicolumn{5}{|c|}{ Station 12} \\
\hline 87 & $1.58=0.36$ & - & $6.63 \pm 4.65$ & $6.18 \pm 4.37$ \\
\hline 147 & $5.48 \pm 2.71$ & - & $9.32 \pm 3.43$ & $6.90 \pm 3.24$ \\
\hline 153 & - & - & $6.37 \pm 1.70$ & - \\
\hline \multicolumn{5}{|c|}{ Thysanoessa inermis } \\
\hline \multicolumn{5}{|c|}{ Station 16} \\
\hline 86 & $1.42 \pm 0.36$ & - & - & - \\
\hline \multicolumn{5}{|c|}{ Station 12} \\
\hline 147 & - & - & $10.11 \pm 3.77$ & $6.01 \pm 2.61$ \\
\hline 153 & - & - & $11.26 \pm 3.38$ & - \\
\hline
\end{tabular}

"Date given in Julian days. 
Table 4. Weights of two species of euphausiids over the middle shelf of the Bering Sea in 1981 (mean dry weight per individual in $\mathrm{mg} \pm$ one standard deviation).

\begin{tabular}{|c|c|c|c|c|}
\hline Date & $\begin{array}{l}\text { Adolescent } \\
\text { Female }\end{array}$ & $\begin{array}{l}\text { Adolescent } \\
\text { Male }\end{array}$ & $\begin{array}{l}\text { Adult } \\
\text { Female }\end{array}$ & $\begin{array}{l}\text { Adult } \\
\text { Male }\end{array}$ \\
\hline \multicolumn{5}{|c|}{ Thysanoessa raschi } \\
\hline \multicolumn{5}{|c|}{ Station 16} \\
\hline $113^{*}$ & $11.0+$ & 8.2 & - & - \\
\hline 122 & 3.1 & $2.9 \pm 0.4$ & - & 6.0 \\
\hline 144 & $14.6 \pm 6.5$ & 5.9 & $13.7 \pm 2.2$ & 12.6 \\
\hline 153 & 13.4 & $9.0 \pm 1.8$ & 28.1 & $11.4 \pm 2.0$ \\
\hline 162 & $15.3 \pm 3.1$ & $13.8 \pm 3.2$ & $20.7 \pm 5.6$ & $16.3 \pm 6.1$ \\
\hline 182 & $19.7 \pm 4.2$ & $17.4 \pm 5.6$ & 32.1 & $15.8 \pm 3.6$ \\
\hline \multicolumn{5}{|c|}{ Station 12} \\
\hline 114 & $3.2 \pm 2.3$ & 2.7 & 6.2 & - \\
\hline 145 & 3.0 & - & - & - \\
\hline 153 & $6.4 \pm 0.4$ & $5.4 \pm 1.4$ & $7.4 \pm 3.4$ & $6.2 \pm 1.0$ \\
\hline 163 & $9.1 \pm 0.1$ & - & - & $8.6 \pm 0.4$ \\
\hline 171 & - & - & $10.4 \pm 1.4$ & 7.5 \\
\hline 180 & - & - & - & 11.6 \\
\hline 193 & 13.4 & - & $17.1 \pm 2.5$ & $15.0 \pm 3.2$ \\
\hline 198 & - & - & $16.1 \pm 1.4$ & $12.8 \pm 2.5$ \\
\hline \multicolumn{5}{|c|}{ Thysanoessa inermis } \\
\hline \multicolumn{5}{|c|}{ Station 16} \\
\hline 122 & $4.3 \pm 2.0$ & - & 一 & - \\
\hline 144 & $11.5 \pm 0.7$ & 一 & - & 21.3 \\
\hline 153 & $13.2 \pm 8.3$ & - & - & - \\
\hline 172 & $19.1 \pm 5.2$ & - & - & - \\
\hline 180 & $20.7 \pm 7.4$ & - & - & - \\
\hline 183 & 26.6 & - & - & - \\
\hline \multicolumn{5}{|c|}{ Station 12} \\
\hline 114 & $2.9 \pm 0.8$ & $4.2 \pm 0.4$ & - & $5.7 \pm 2.2$ \\
\hline 145 & $5.5 \pm 1.7$ & - & - & - \\
\hline 153 & $8.9 \pm 2.4$ & - & - & 9.5 \\
\hline 163 & $10.4 \pm 2.7$ & - & 19.3 & - \\
\hline 193 & - & - & $18.6 \pm 4.9$ & - \\
\hline
\end{tabular}

*Date given in Julian days.

†No standard deviation indicates only one specimen was measured.

was not very abundant at either station in either year (Tables 3 and 4); therefore we are unable to draw any conclusions about the effect of interannual temperature differences on $T$. inermis. The seasonal development in size of adult and adolescent males and females of $T$. raschi revealed that in 1981 these stages were always larger (had greater dry weight) at Station 16 compared with Station 12 (Fig. 9). The differences in dry weight among adult females of $T$. raschi were largest observed (Fig. 9). The only stage of $T$. inermis for which enough individuals were captured to make any generalizations were adolescent females, and they showed the same trend; at all times in 1981 adolescent females at Station 16 were larger than those at Station 12 (Fig. 10).

Secondary production is defined as the addition of mass to an individual during a specified interval of time (Edmondson \& Winberg 1971). When considering reproductive female euphausiids, both growth of somatic tissue and egg laying are components of secondary production because females continue to gain weight and increase in body length after reaching adulthood (Lasker 1966). For subadult individuals, both somatic growth and the exoskeleton are components. Because we reared the eggs of $T$. raschi through the calyptopis I stage at sea, we have estimates of stage duration for eggs $(1.9 \mathrm{~d})$ and the three naupliar stages (nauplius $\mathrm{I}=2.1 \mathrm{~d}$; nauplius $\mathrm{II}=$ $2.5 \mathrm{~d}$; metanauplius $=4.3 \mathrm{~d}$ ). Combining these mean stage durations (number of observations $=$ 18) with mean weights of the various stages allows calculation of the specific growth rate of the early stages (Table 5). Although naupliar stages are commonly considered non-feeding, growth of the nauplius I stage was occurring in 1981 and decreased through the sampling season from 
PROBES 1981 T $1.75 \mathrm{CH}$
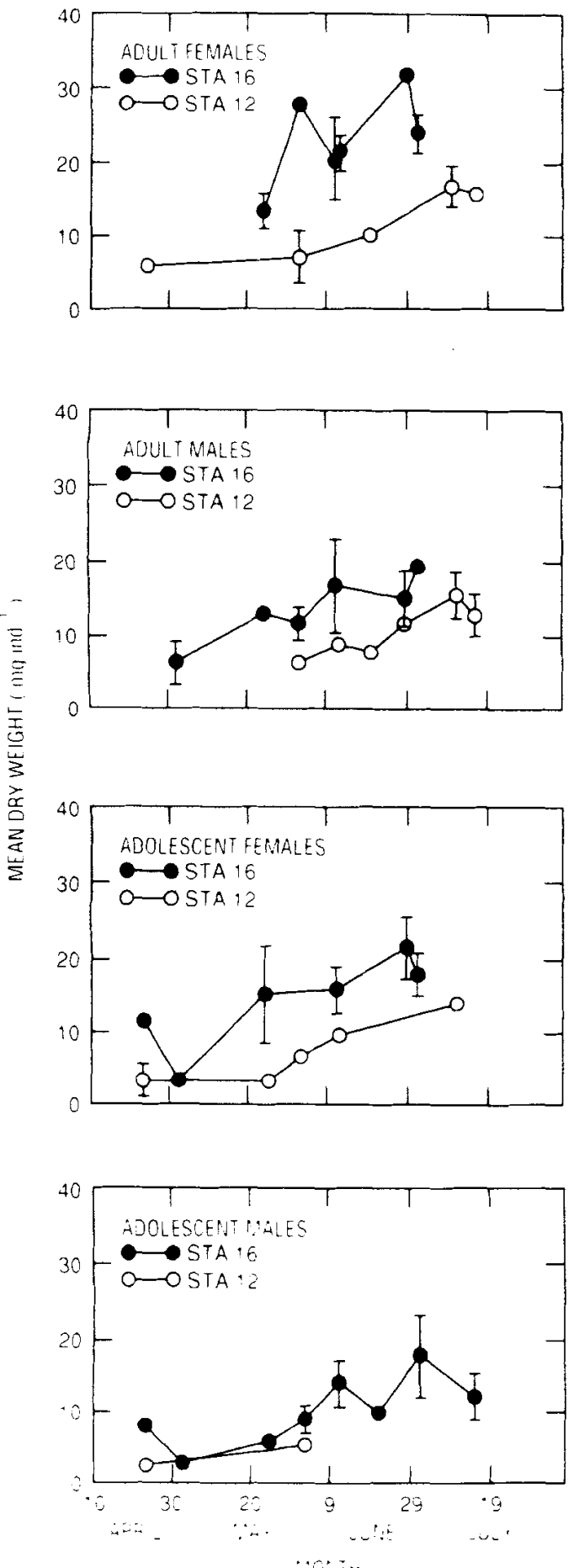

Fig. 9. Seasonal development of biomass (dry weight) of larger stages of $T$, raschi in 1981. Error bars indicate onc standard deviation of the mean.
PROBES 1981 T ImPIIm/S
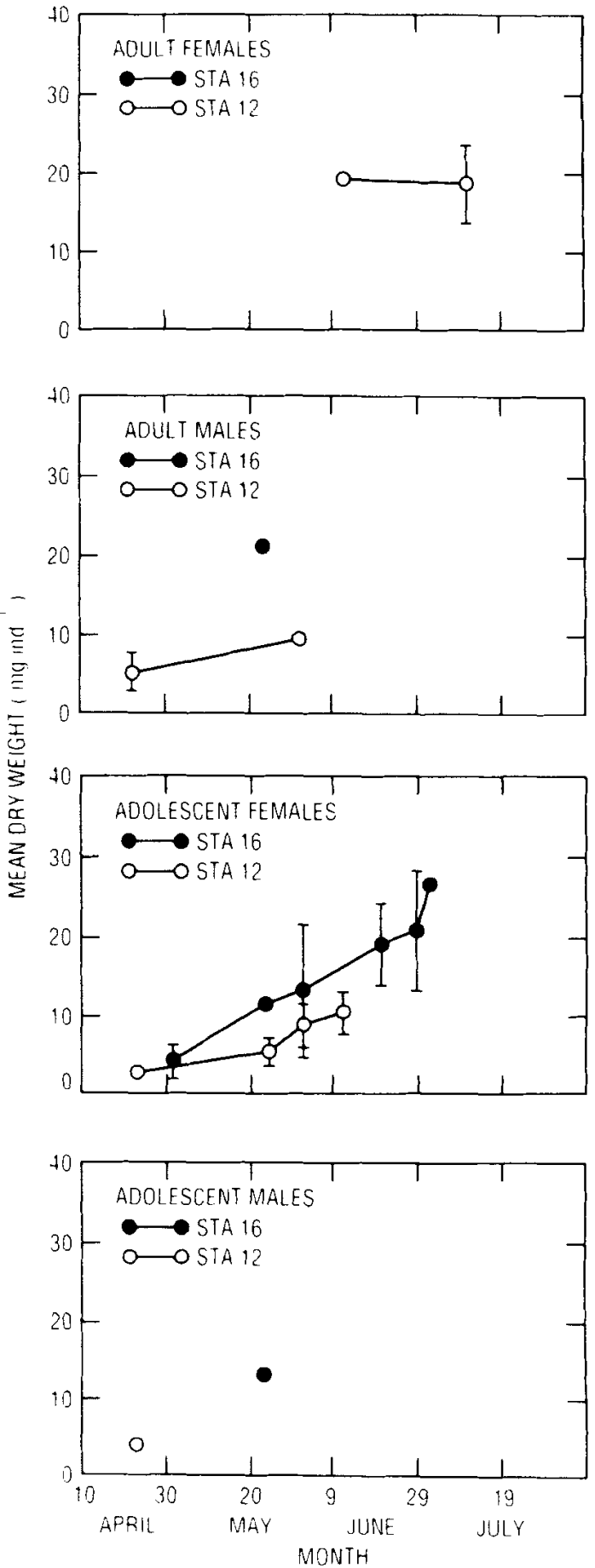

Fig. 10. Seasonal development of biomass (dry weight) of larger stages of $T$. inermis in 1981. Error bars indicate one standard deviation of the mean. 
Table 5. Weight and specific growth rates of nauplii and calyptopis stages of Thysanoessa raschi in the Bering Sea in 1981.

\begin{tabular}{|c|c|c|}
\hline & $\begin{array}{l}\text { Dry Weight } \\
\left(\mu \mathrm{g} \cdot \text { individual }^{-1}\right)\end{array}$ & (\% Dry Weight $\cdot$ Day $\left.^{-1}\right)$ \\
\hline \multicolumn{3}{|l|}{ 1-25 May } \\
\hline Nauplius I & $3.75 \pm 0.01(n=2)$ & 13.5 \\
\hline Nauplius II & $4.98 \pm 0.15(\mathbf{n}=3)$ & -1.5 \\
\hline Metanauplius & 4.79 & - \\
\hline Calyptopis I & none & - \\
\hline Calyptopis II & none & - \\
\hline Calyptopis III & none & - \\
\hline \multicolumn{3}{|l|}{31 May-23 June } \\
\hline Nauplius I & $3.52 \pm 0.20(n=4)$ & 8.3 \\
\hline Nauplius II & $4.19 \pm 0.56(n=3)$ & 1.6 \\
\hline Metanauplius & $4.36 \pm 0.25(n=2)$ & 1.6 \\
\hline Calyptopis I & $4.67 \pm 0.81(n=4)$ & $(11.5)^{*}$ \\
\hline Calyptopis II & $7.40 \pm 0.96(n=3)$ & $(5.2)^{*}$ \\
\hline Calyptopis III & $9.11 \pm 2.70(n=4)$ & - \\
\hline \multicolumn{3}{|l|}{27 June-18 July } \\
\hline Nauplius I & $3.49 \pm 0.30(n=10)$ & 6.5 \\
\hline Nauplius II & $4.00 \pm 0.34(n=2)$ & 0 \\
\hline Metanauplius & $3.99 \pm 0.33(n=5)$ & 3.1 \\
\hline Calyptopis I & $4.55 \pm 0.54(n=4)$ & $(9.0)^{*}$ \\
\hline Calyptopis II & $6.53 \pm 1.33(n=2)$ & $(14.5)^{*}$ \\
\hline Calyptopis III & $11.65 \pm 0.92(n=3)$ & - \\
\hline
\end{tabular}

"Growth computed using stage durations of $4 \mathrm{~d}$ for Calyptopis I and $4 \mathrm{~d}$ for Calyptopis II at $8^{\circ} \mathrm{C}$ from Ponomareva 1966.

$13.5 \%$ dry body weight per day in spring to $6.5 \%$ per day in summer (Table 5). Growth rates of later naupliar stages were slower (Table 5). Growth of calyptopis stages was estimated using weights we measured and the duration of these stages suggested by Ponomareva (1966). Growth rates of calyptopis stages were generally higher than those of naupliar stages (Table 5) with a maximum of $14.5 \%$ dry body weight per day estimated for calyptopis II in early July. Our data for 1980 are less complete, showing no growth by the naupliar stages present in March and April, and slow growth (ca. $0.5 \% \mathrm{~d}^{-1}$ ) in late May and early June.

Females laid relatively large numbers of eggs during the first three days after capture (Fig. 11). Using an average weight of $3.012 \mu \mathrm{g}$ dry weight per egg $( \pm 0.382 ; n=8)$, egg release corresponded to an average of $3.6 \%$ of female body weight per day $( \pm 1.8 ; \mathrm{n}=58$; range $=0$ to $8.7 \%$ ). Average egg production on the first day after capture converted to $3.8 \%$ dry body weight of the female per day; on the second day, $3.4 \%$; and on the third day $3.5 \%$.

Changes observed in average biomass of adolescents and adults with time can be used to estimate somatic growth rates of older individ- uals. Data for the cold and stormy year, 1980, are few and are primarily for $T$. raschi at Station 16 (Table 3). Growth rates calculated for periods in which growth was positive show that for both $T$. raschi and $T$. inermis in 1980, growth was about

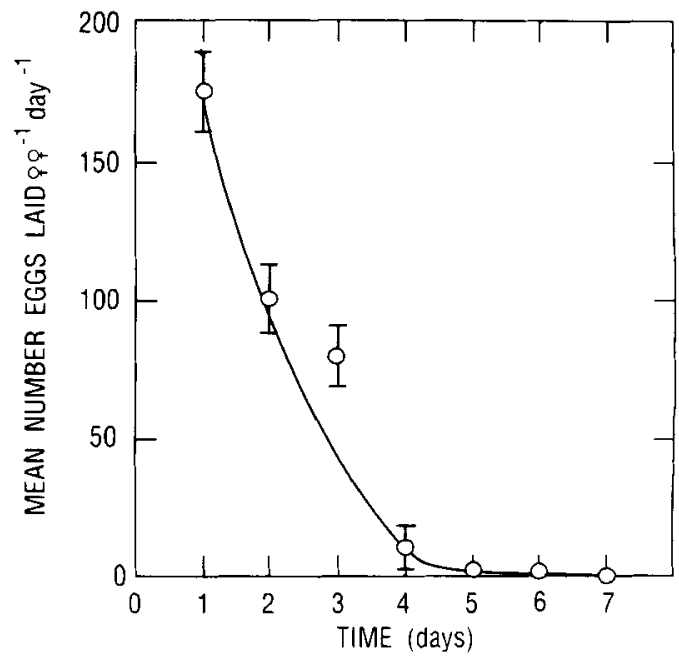

Fig. 11. Average egg production by female $T$, raschi in 1981 . Error bars indicate one standard error of the mean. 
Table 6. Estimated somatic growth for euphausiids on the Bering Sea shelf in 1980.

\begin{tabular}{|c|c|c|c|c|}
\hline Taxon & Sex & Station & Date & $\%$ Dry Wt. Day ${ }^{-1}$ \\
\hline T. raschi & Adult male & 16 & $104-145^{*}$ & 1.8 \\
\hline T. raschi & Adult female & 16 & $86-145$ & 1.6 \\
\hline \multirow[t]{4}{*}{ T. raschi } & Adolescent female & 16 & $86-104$ & 1.5 \\
\hline & & & $86-145$ & 2.3 \\
\hline & & & $104-145$ & 2.7 \\
\hline & & & $86-153$ & 1.9 \\
\hline$T$. raschi & Adult male & 12 & $87-147$ & 1.8 \\
\hline T. raschi & Adult female & 12 & $87-147$ & 0.6 \\
\hline T. raschi & Adolescent female & 12 & $87-147$ & 2.1 \\
\hline$T$. inermis & Adolescent female & 12 & $147-153$ & 1.8 \\
\hline
\end{tabular}

*Date given in Julian days.

Table 7. Estimated somatic growth for euphausiids on the Bering Sea shelf in 1981.

\begin{tabular}{|c|c|c|c|c|}
\hline Taxon & Sex & Station & Date & $\%$ Dry Wt. Day ${ }^{-1}$ \\
\hline \multirow[t]{3}{*}{ T. raschi } & Adult male & 16 & $122-153^{*}$ & 2.1 \\
\hline & & & $153-162$ & 4.0 \\
\hline & & & $162-182$ & -0.2 \\
\hline \multirow[t]{2}{*}{ T. raschi } & Adult female & 16 & $144-162$ & 2.4 \\
\hline & & & $162-182$ & 2.2 \\
\hline \multirow[t]{4}{*}{ T. raschi } & Adolescent male & 16 & $122-144$ & 3.1 \\
\hline & & & $144-153$ & 4.7 \\
\hline & & & $153-162$ & 4.7 \\
\hline & & & $162-182$ & 1.1 \\
\hline \multirow[t]{3}{*}{ T. raschi } & Adolescent female & 16 & $122-144$ & 7.0 \\
\hline & & & $144-162$ & 0.3 \\
\hline & & & $162-182$ & 1.3 \\
\hline \multirow[t]{3}{*}{ T. raschi } & Adult male & 12 & $153-163$ & 3.3 \\
\hline & & & $163-180$ & 1.8 \\
\hline & & & $180-193$ & 2.0 \\
\hline \multirow[t]{2}{*}{ T. raschi } & Adult female & 12 & $153-171$ & 1.9 \\
\hline & & & $171-193$ & 2.3 \\
\hline T. raschi & Adolescent male & 12 & $114-153$ & 1.8 \\
\hline \multirow[t]{3}{*}{ T. raschi } & Adolescent female & 12 & $145-153$ & 9.4 \\
\hline & & & $153-163$ & 3.5 \\
\hline & & & $163-193$ & 1.3 \\
\hline$T$. inermis & Adult male & 16 & One in samples & \\
\hline$T$. inermis & Adult female & 16 & None in samples & \\
\hline \multirow[t]{4}{*}{$T$. inermis } & Adolescent female & 16 & $122-144$ & 4.5 \\
\hline & & & $144-153$ & 1.5 \\
\hline & & & $153-172$ & 1.9 \\
\hline & & & $172-180$ & 1.0 \\
\hline T. inermis & Adult male & 12 & $114-153$ & 1.3 \\
\hline$T$. inermis & Adult female & 12 & $163-193$ & -0.1 \\
\hline \multirow[t]{3}{*}{ T. inermis } & Adolescent female & 12 & $114-145$ & 2.1 \\
\hline & & & $145-153$ & 6.0 \\
\hline & & & $153-163$ & 1.3 \\
\hline
\end{tabular}

-Date is given in Julian days

$2 \%$ dry body weight per day (Table 6). Data are more complete for 1981 (Table 7), but it is clear that $T$. inermis was generally scarce in the middle shelf region. Growth of adolescent female $T$. inermis at Station 16 was highest early in the sampling season (April and May 1981), whereas at Station 12 growth was highest in May (Table 7). Adolescent females were the only stage of $T$. 

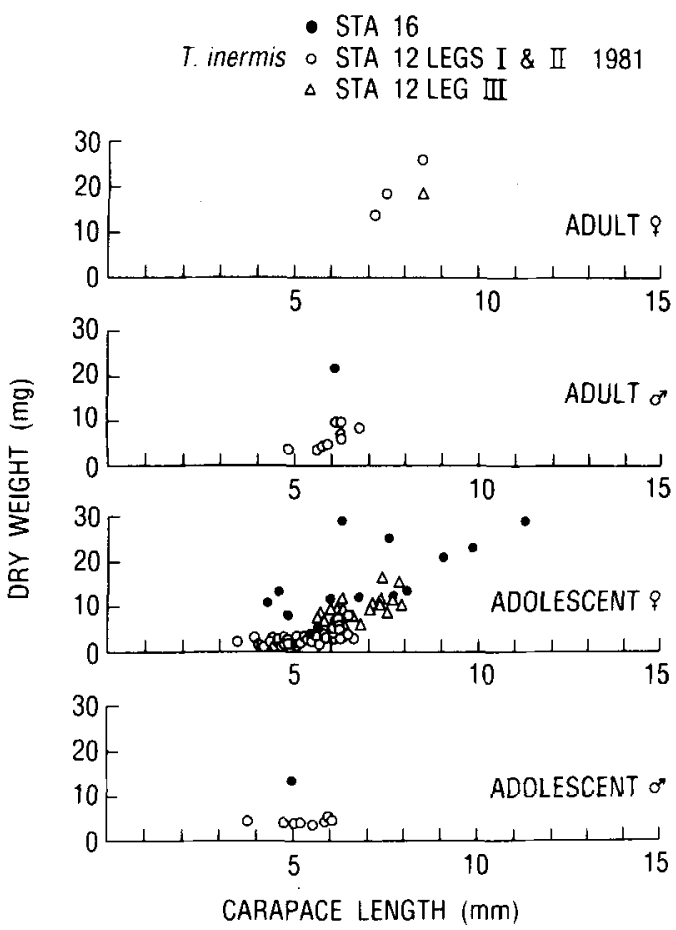

Fig. 12. Correlation of carapace length and dry weight of larger stages of $T$. inermis in 1981. Increases in length and weight between early and late spring are most apparent in adolescent females.

inermis captured often enough and in sufficient numbers to allow estimates of growth over the middle shelf. In June, growth of $T$. inermis was higher at Station 16 than at Station 12, but at the end of the sampling season (July) growth of $T$. inermis was slow at Station 16 and the species was not captured at Station 12 (Table 7). For any given carapace length, the biomass of $T$. inermis was generally greater at Station 16 compared with Station 12; the largest $T$. inermis captured over the middle shelf occurred at Station 16 (Fig. 12).

In 1981, all stages of $T$. raschi at Station 16, except adolescent females, showed highest growth rates in late May and early June (ca. Julian days 145-160, Table 7). After mid-June (Julian day 165), growth rates of adolescent and adult $T$. raschi declined to 1 to $2 \%$ dry body weight per day at Station 16 (Table 7). At Station 12, $T$. raschi were rarely captured until June (Table 4). Except for adult females, growth of $T$. raschi at Station 12 in June (Julian days 152-181) was higher than in July (Julian days 182-195, Table 7). As with $T$. inermis, most of the $T$. raschi

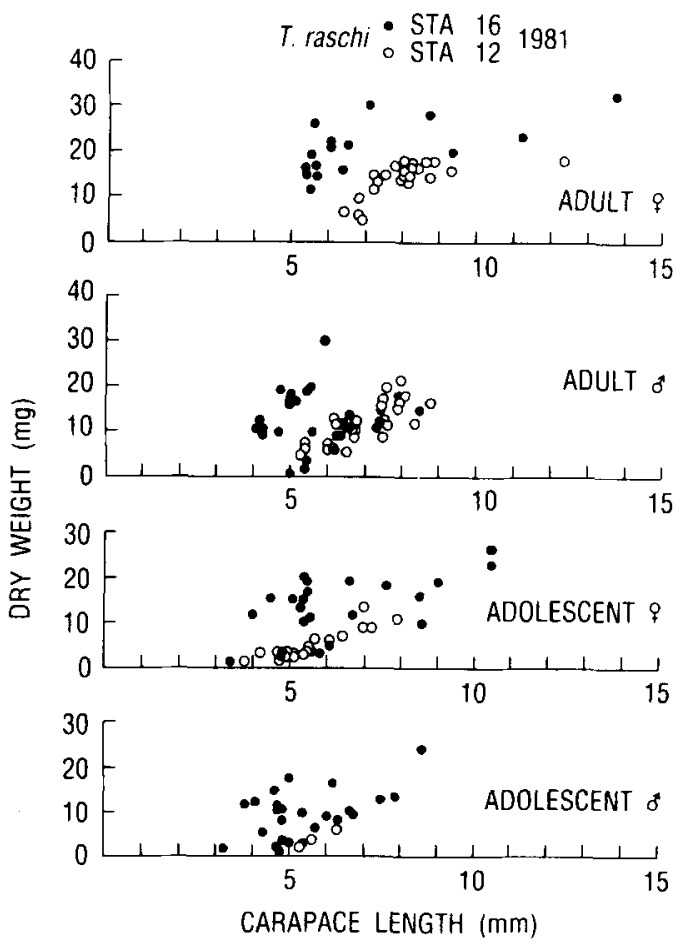

Fig. 13. Correlation of carapace length and dry weight of larger stages of $T$. raschi in 1981 .

captured at Station 16 were larger than their counterparts collected at Station 12 (Fig. 13). In 1980, however, $T$. raschi were the same size at Stations 12 and 16 and in general much smaller than the T. raschi collected in 1981 (Fig. 14).

We have not investigated the proportion of gravid females among the adult females, so it is presently impossible to evaluate total secondary production of the euphausiid population of the middle shelf habitat. The overall estimate should approximate the sum of secondary production estimated by weight increments and secondary production estimated by egg production. At Station 12 , this is a maximum of $5.9 \%$ dry body weight per day for $T$. raschi and no growth for $T$. inermis in 1981. At Station 16, the estimate is $6.0 \%$ dry body weight per day for $T$. raschi; adult females of $T$. inermis were not captured. Similarly for $1980, T$. inermis females were not captured. Estimated secondary production of $T$. raschi females at Station 12 was $4.2 \%$ dry body weight per day and at Station 16 the estimate was $5.2 \%$ per day. 


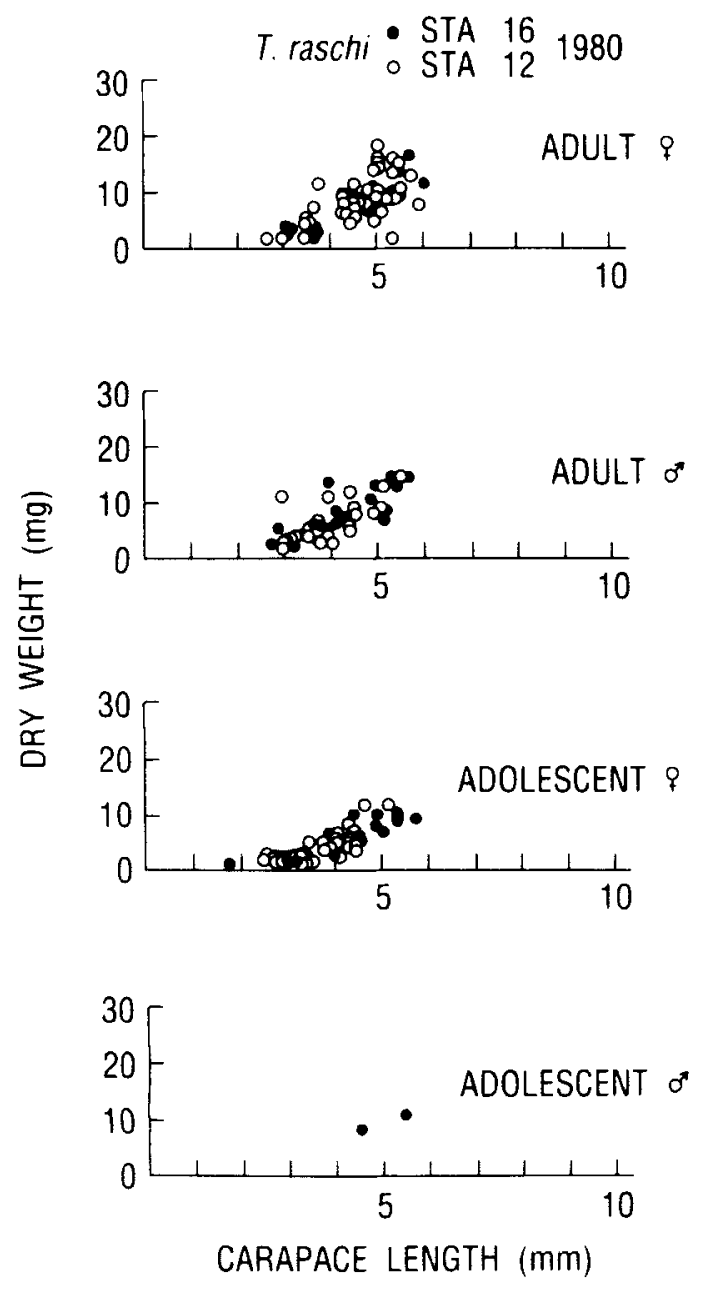

Fig. 14. Correlation of carapace length and dry weight of larger stages of $T$, raschi in 1980.

\section{Discussion}

Although 1980 was cold and stormy and 1981 was relatively warm and calm, depletion of nitrate in surface waters of the stations of the middle shelf was similar both years (Fig. 15). Some uptake of nitrate occurred in April, but most of the conversion of nitrate to phytoplankton biomass took place in May. By the end of May at both Stations 12 and 16 in both 1980 and 1981, surface nitrate was depleted (Fig. 15). Corresponding concentrations of chlorophyll $a$ were low and increasing in April, reaching their maxima in May of both years (Fig. 16). There is nothing apparent in this estimate of food supply to explain why

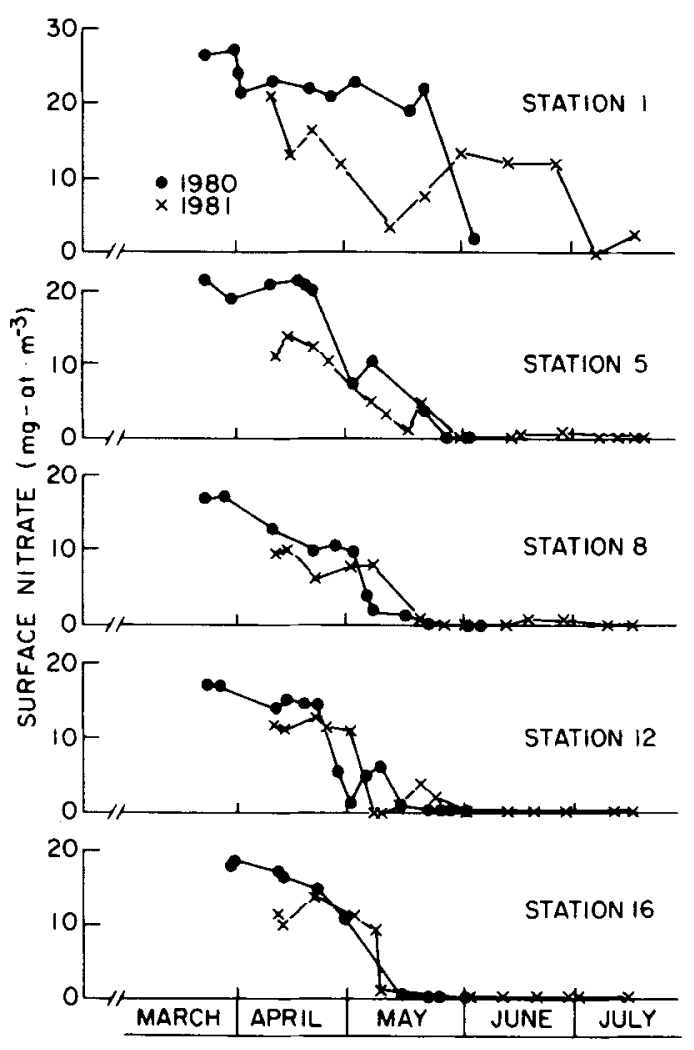

Fig. 15. Seasonal pattern of the concentration of nitrate at the surface along the PROBES section in 1980 and 1981 . All stations on the continental shelf are depleted of nitrogen by late May.

Thysanoessa raschi were similarly sized at both stations in 1980 but in general were larger at Station 16 in 1981 . Therefore, the rather strong contrast in temperature between the two years may be invoked as the reason for the difference in size; in the warmer year the euphausiids grew to a larger size. Growth rates of $T$. raschi were higher in 1981 compared with 1980. Additional effects, such as overwintering conditions and growth in 1979, which were not studied may also have influenced the 1980 and 1981 observations.

Secondary production by these species of euphausiids have been measured elsewhere, and the estimates show that in the North Sea in spring Thysanoessa inermis grew at a rate of $1.5 \%$ dry body weight per day in the entire study period (mid-March to early June; Lindley \& Williams 1980). Similar rates were measured in this study when the entire sampling period was used. When portions of the sampling period were analyzed 


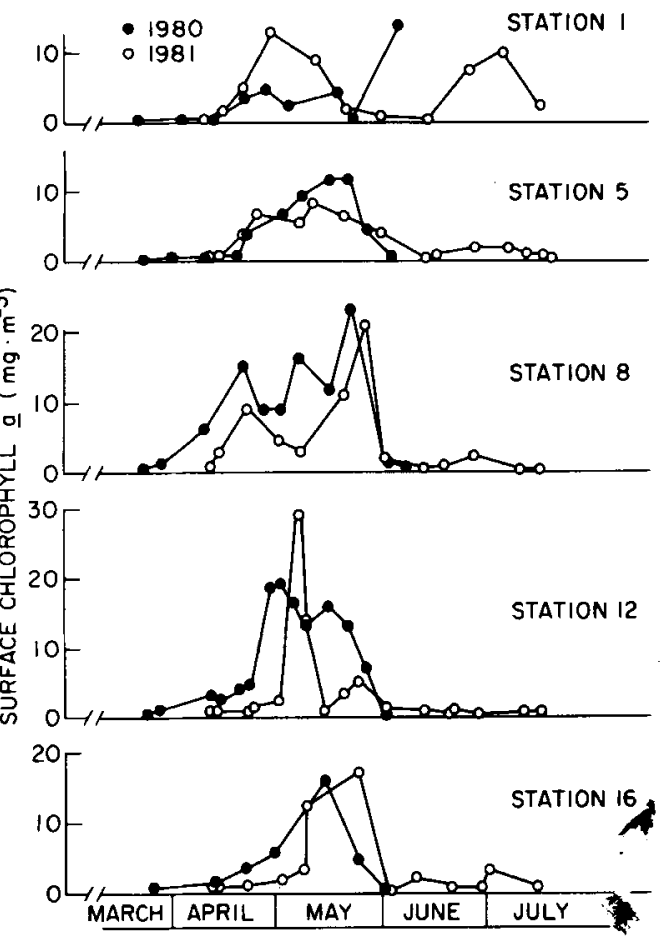

Fig. 16. Seasonal pattern of chlorophyll $a$ at the surface along the PROBES section in 1980 and 1981. All stations on the continental shelf are depleted of chlorophyll $a$ in June.

separately, growth rates were higher early in the season. In the North Sea in spring, growth nearly quadrupled during and after the spring bloom of phytoplankton (Lindley \& Williams 1980). Similarly, in the fjord Balsfjorden, $T$. raschi grew at a rate of $1.7 \%$ dry body weight per day in the March-August period and $T$. inermis at a rate of $1.2 \%$ in the same time period (Hopkins et al. 1984). What we have observed in the Bering Sea is that during an unusually warm growing season with abundant food, growth rates can be increased substantially. Increased growth rates did not result in markedly increased standing stocks however.

It has been shown in $T$. inermis that lipid synthesis can proceed at a rate of $0.2 \%$ body weight per day, and therefore lipid synthesis may comprise a considerable proportion of daily growth (Henderson et al. 1981). Lipid accumulation patterns in Balsfjorden have shown that $T$. inermis sequesters wax esters, considered to be the long term metabolic reserve of polar zooplankton (Sargent \& Whittle 1981), earlier than does $T$, raschi and that the wax ester concentrations in $T$. inermis always exceed those of $T$. raschi (Falk-Petersen et al. 1982). The composition of the lipids in $T$. raschi suggests that its diet includes detritus and animal prey (Falk-Petersen et al. 1982). The timing of lipid sequestration and utilization and the types of lipid associated with the two species has led to the hypothesis that $T$. inermis has a more truly polar life history than $T$. raschi; in winter its metabolism relies entirely on lipid reserves (Hopkins et al. 1984, 1985). This does not seem to be true of $T$. inermis in the North Sea, however, where individuals sequester much less lipid (FalkPetersen 1981).

In the middle shelf of the Bering Sea, many older adolescent females, adult females, and adult males of $T$. raschi had considerable accumulations of an opaque, yellowish brown material under the carapace. Elsewhere, in the Sea of Okhotsk and the Sea of Japan, such observed accumulations were found to be composed of lipid and polysaccharide which appeared to be used for the synthesis of oocytes in spring (Ponomareva 1966). In the Bering Sea, between 30 and $70 \%$ of the $T$. raschi captured at the end of April in the upper $10 \mathrm{~m}$ both day and night already had such material deposited under the carapace. Since spawning was probably not until May over the middle shelf, the material could yet be used for oocyte formation.

Secondary production (this study) and respiration rates (Vidal \& Whitledge 1982) of the Bering Sea euphausiids can be used to calculate ingestion rates (Smith \& Lane 1988) if one assumes a $70 \%$ assimilation efficiency (Conover 1966). If we allow the biomass of euphausiids present at the beginning of the spring bloom of phytoplankton (1 May) to grow at some specified percentage of their dry body weight per day (3 or $8 \%$ ), we arrive at ingestion rates for the spring bloom period (1 May-10 June) that vary between 6 and $193 \mathrm{mgC} \mathrm{m}^{-2} \mathrm{~d}^{-1}$ for Stations 12 and 16 in 1980 and 1981 (Table 8). This amounts to very little of the daily primary production over the middle shelf in 1980 (maximum of $6 \%$ ) or 1981 (maximum of $1 \%$; carbon productivity calculated from Sambrotto et al. 1986, using a $C: N$ of 7 ). Primary production in terms of carbon measured at Station 12 during the bloom in 1980 ranged from 3500 to $4500 \mathrm{mgC} \mathrm{m}^{-2} \mathrm{~d}^{-1}$ (Iverson pers. comm.) Similarly low rates of potential use of the spring bloom by euphausiids were observed in the North Sea also (Lindley \& Williams 1980). The 
Table 8. Secondary production and ingestion during the spring bloom of phytoplankton in 1980 and 1981.

\begin{tabular}{lcr}
\hline & $\begin{array}{c}\text { Secondary } \\
\text { Production } \\
\left(\mathrm{mgC} \cdot \mathrm{m}^{-2} \cdot \mathrm{day}^{-1}\right)\end{array}$ & $\begin{array}{c}\text { Ingestion } \\
\left(\mathrm{mgC}^{-2} \cdot \mathrm{day}^{-1}\right)\end{array}$ \\
\hline 1980 & & 14 \\
Station 12,3\% growth & 5 & 73 \\
Station 12,8\% growth & 47 & 39 \\
Station 16,3\% growth & 14 & 193 \\
Station 16, 8\% growth & 124 & 6 \\
1981 & 2 & 17 \\
Station 12,3\% growth & 10 & 7 \\
Station 12,8\% growth & 3 & 37 \\
Station 16, 3\% growth & 24 & \\
Station 16, 8\% growth & & \\
\hline
\end{tabular}

rates are higher for 1980 in the Bering Sea because of the higher biomass of euphausiids present there at the beginning of May that year.

The small bodied copepods that share the middle shelf region with the euphausiids probably do not consume much of the spring bloom (Vidal \& Smith 1986), leaving a substantial portion of the phytoplankton available for a benthic food chain containing a large population of Chionoecetes opilio (Tanner crab) whose center of abundance is in the middle shelf (Incze 1983). The zoeas of the Tanner crabs and nauplii of euphausiids co-occur in the upper $20 \mathrm{~m}$. Chionoecetes opilio zoeas begin to appear in the plankton in late April and remain there until early July (Incze 1983). Since the larvae of $C$. bairdi are predators upon the nauplii of the middle shelf euphausiids (Incze 1983), the timing of the hatching $C$. opilio and the spawning of the euphausiids of the middle shelf suggest that crab zoea likely prey upon euphausiid nauplii (Fig. 17)

Predation, probably by birds, mammals, and fish, substantially reduced the numbers of largebodied copepods in the outer shelf region in May of 1980 and 1981 (Smith \& Vidal 1986). Observations of the stomach contents of birds collected over the middle shelf showed that the diet of shearwaters was approximately $30 \% \mathrm{~T}$. raschi and $47 \%$ euphausiids, whereas over the inner shelf the proportion was about $70 \%$ T. raschi and $90 \%$ euphausiids (Schneider et al. 1986). A major distinction between the outer shelf of the Bering Sea and the middle shelf is that non-diving species of birds occupy the slope and outer shelf regions while diving species, shearwaters, murres and puffins. occupy the middle and inner shelf regions
(Schneider et al. 1986). Substantial interannual variability was found in the mass of seabirds occupying the middle shelf in 1980 and 1981; in 1981 the value was twice that of 1980 (Schneider et al. 1986). This, and the preference of the diving birds for euphausiids, suggest that predation in 1981 should have been higher than in 1980 . It is not

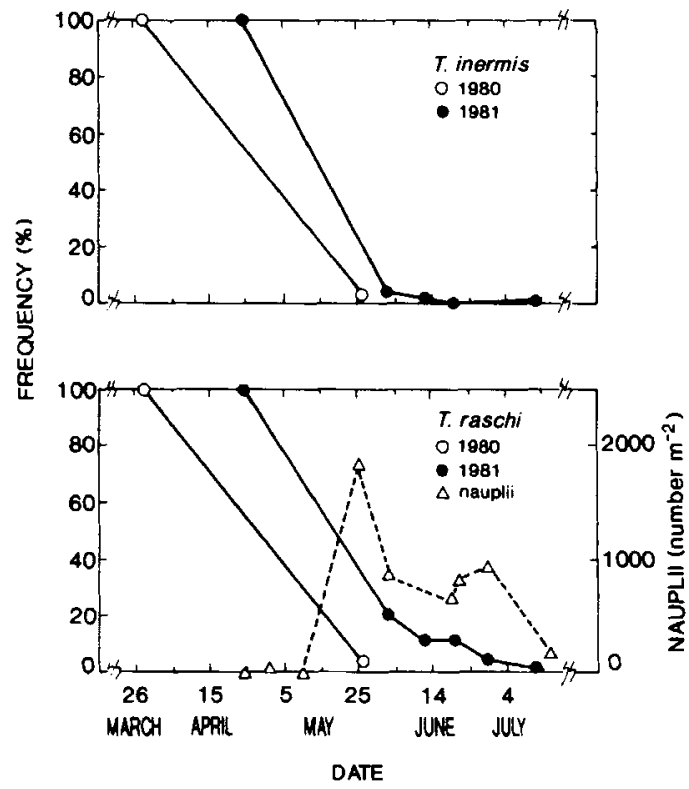

Fig. 17. Proportional changes in the total numbers of adolescent and adult $T$. raschi and $T$. inermis with time in the middle shelf region (Station 12) in 1980 and 1981 and the abundance of euphausiid nauplii at Station 12 with time in 1981. The spring bloom of phytoplankton occurred approximately between 25 April and 25 May both years. 
clear that the euphausiids of the middle shelf in 1981 experienced heavier predation (Fig. 17). In both years the numbers of adolescent and adult euphausiids declined sharply between the spring period prior to the bloom of phytoplankton and the period just after the bloom (Fig. 17). In both years the numbers of $T$. raschi and $T$. inermis declined by 80 to $100 \%$ in the $40-50$ days of the spring bloom. Sampling in October of 1981 at Stations 12 and 16 at night revealed that there were no $T$. inermis present in the middle shelf habitat in autumn. $T$. raschi, however, were present as furcilia at Station $12\left(26 \mathrm{~m}^{-2}\right)$ and as adolescents at Station $16\left(37 \mathrm{~m}^{-2}\right)$. If those numbers survive winter, they are just adequate to produce the maximum numbers of nauplii observed in spring. That is, twenty female $T$. raschi laying 100 eggs per day (Fig. 11) result in 2000 nauplii per day. The maximum numbers of nauplii observed at Station 12 in 1981 were $2000 \mathrm{~m}^{-2}$ (Fig. 17). It would seem that the abundant food, present as phytoplankton cells, detritus, nauplii of small copepods, or protozoans, in the middle shelf habitat should support many more euphausiids than are observed. The simplest conclusion is that the combination of predators present in the middle shelf-diving birds, pollack, Tanner crabs, whales, and seals-control the euphausiid population very effectively.

Acknowledgements. - This research was funded by the Division of Polar Programs of the U.S. National Science Foundation under grant DPP76-23340. U.S. Department of Energy contract number DE-AC02-76CH00016 funded the writing of the paper. The field work was completed with help from our colleagues in PROBES and the crew of the R/V THOMAS THOMPSON. Assistance at sea was provided by P. V. Z. Lane, J. C. Dugas, B.. A. Plonski, L. S. Incze, J. Judson, M. Rochet, and C. Smith. Laboratory analyses were done by C. Geiger, P. V. Z. Lane, J. C. Dugas, B. A. Plonski, and E. M. Schwarting. D. G. Smith assisted in data reduction. Suggestions of C. C. E. Hopkins, J. Mauchline, and an anonymous reviewer improved the manuscript. I am especially indebted to J. Vidal who was my collaborator in all aspects of this project and to the Pro Mare program for sponsorship of the Symposium and for funding my participation in it.

\section{References}

Berkes. F. 1977: Production of the euphausiid crustacean Thysanoessa raschii in the Gulf of St. Lawrence. J. Fish Res. Board Can. 34, 443-446.

Boden, B. P., Johnson. M. W. \& Brinton, E. 1955: The euphausiacea (Crustacea) of the North Pacific. Bull. Scripps Inst. Ocean. 6, 287-400.
Brinton, E. 1962: The distribution of Pacific euphausiids. Bull. Scripps Inst. Ocean. 8, 51-270.

Coachman. L. K. 1986: Circulation, water masses, and fluxes on the southeastern Bering Sea shelf. Cont. Shelf Res. 5, 23-108.

Coachman, L. K. \& Charnell, R. L. 1979: On lateral water mass interaction - a case study, Bristol Bay, Alaska. J. Phys. Oceanogr. 6, 278-297.

Conover, R. J. 1966: Assimilation of organic matter by zooplankton. Limnol. Oceanogr. 11, 338-354.

Cooney, R. T. \& Coyle, K. O. 1982: Trophic implications of cross-shelf copepod distributions in the southeastern Bering Sea. Mar. Biol. 70. 187-196.

Davis, C. C. 1982: A preliminary quantitative study of the zooplankton from Conception Bay, insular Newfoundland, Canada. Revue Ges. Hydrobiol. 67. 713-747.

Edmondson, W. T. \& Winberg, G. G. 1971: A manual on methods for the assessment of secondary productivity in fresh waters. IBP handbook No. 17, Blackwell Scientific Publications, Oxford. $358 \mathrm{pp}$.

Einarsson. H. 1945: Euphausiacea. 1. Northern Atlantic species. Reprinted from Dana Report 27 by Bianco Luno, Copenhagen. $191 \mathrm{pp}$.

Falk-Petersen, S. 1981: Ecological investigations on the zooplankton community of Balsfjorden, northern Norway: seasonal changes in body weight and the main biochemical composition of Thysanoessa inermis (Krøyer), T. raschi (M. Sars), and Meganyctiphanes norvegica (M. Sars) in relation to environmental factors. J. Exp. Mar. Biol Ecol. 49, 103-120.

Falk-Petersen, S., Sargent. J. R., Hopkins, C. C. E. \& Vaja, B. 1982: Ecological investigations on the zooplankton community of Balsfjorden, northern Norway: lipids in the euphausiids Thysanoessa raschi and $T$. inermis during spring. Mar. Biol. 68, 97-102.

Fukuchi, M. 1977: Regional distribution of amphipoda and euphausiacea in the northern North Pacific and Bering Sea in summer of 1969. Res. Inst. N. Pac. Fish., Hokkaido Univ., Spe. Vol., 439-458.

Geiger, S. R., Rodriguez, K. \& Murilla, M. M. 1968: Euphausiacea of the Arctic Ocean and its peripheral seas. Bull. So. Calif. Acad. Sciences 67, 69-79.

Henderson, R. J., Sargent, J. R. \& Falk-Petersen, S. 1981: Lipogenesis in the Arctic euphausiid Thysanoessa inermis. Mar. Biol. 63, 235-240.

Hopkins, C. C. E., Tande, K. S., Gronvik, S. \& Sargent, J. R. 1984: Ecological investigations of the zooplankton community of Balsfjorden, northern Norway: an analysis of growth and overwintering tactics in relation to niche and environment in Metridia longa (Lubbock), Calanus finmarchicus (Gunnerus), Thysanoessa inermis (Krøyer) and $T$. raschi (M. Sars). J. Exp. Mar. Biol. Ecol. 82, 77-99.

Hopkins, C. C. E., Tande, K. S., Grönvik, S., Sargent, J. R. \& Schweder, T, 1985: Ecological investigations of the zooplankton community of Balsfjorden, northern Norway: growth, and quantification of condition, in relation to overwintering and food supply in Metridia longa. Calanus finmarchicus, Thysanoessa inermis and Thysanoessa raschi. Pp. 83-100 in Gray, J. S. \& Christiansen, M. E. (eds.): Marine Biology of Polar Regions and Effects of Stress on Marine Organisms. J. Wiley and Sons. New York.

Incze, L. S. 1983: Larval life history of Tanner crabs, Chionoecetes bairdi and $C$. opilio, in the southeastern Bering Sea and relationships to regional oceanography. Ph.D. thesis, University of Washington. Seattle. $191 \mathrm{pp}$. 
Lasker, R. 1966: Feeding, growth, respiration, and carbon utilization of a euphausiid crustacean. J. Fish. Res. Bd. Canada 23, 1291-1317.

Lindley, J. A. 1980: Population dynamics and production of euphausiids. II. Thysanoessa inermis and $T$. raschi in the North Sea and American coastal waters. Mar. Biol. 59. 225-233.

Lindley, J. A. \& Williams, R. 1980: Plankton of the Fladen Ground during FLEX 76. II. Population dynamics and production of Thysanoessa inermis (Crustacea: Euphausiacea). Mar. Biol. 57, 79-86.

Macdonaid, R, 1928: The life history of Thysanoessa raschii. $J$. Mar. Biol. Ass. U.K. 15, 57-79.

Mauchline, J. \& Fisher, L. R. 1969: The biology of euphausiids. Ado. Mar. Biol. 7. 1-454.

Minoda, T. \& Marumo, R. 1974: Regional characteristics of distribution of phyto- and zooplankton in the Eastern Bering Sea and Chukchi Sea in June-July. 1972. Pp. 83-95 in Takenouti, Y. \& Hood. D. (eds.): Bering Sea oceanography: an update. Inst. Mar. Res., Univ. Alaska, Fairbanks.

Nemoto. T. 1957: Foods of baleen whales in the Northern Pacific. The scientific reports of the whales research institute $12,33-89$.

Niebauer, H. J., McRoy, C. P. \& Goering, J. J. 1982a: March-June 1980 Hydrographic (Bottle) Data. PROBES Data Report PDR 82-008, Institute of Marine Science, University of Alaska, Fairbanks. 399 pp.

Niebauer, H. J., McRoy, C. P. \& Goering, J. J. 1982b: April-July 1981 Hydrographic (Bottle) Data. PROBES Data Report PDR 82-012. Institute of Marine Science. University of Alaska, Fairbanks. 496 pp.

Ponomareva, L. A. 1966: Euphausiids of the North Pacific their distribution and ecology. Translated from Russian by S. Nemchonok. Israeli Program for Scientific Translations. Jerusalem. 154 pp.

Sambrotto, R. N., Niebauer, H. J., Goering, J. J. \& Iverson, R. L. 1986: Relationships among vertical mixing, nitrate uptake, and phytoplankton growth during the spring bloom in the southeast Bering Sea middle shelf. Cont. Shelf Res. 5, 161-198.

Sargent, J. R. \& Whittle. K. J. 1981: Lipids and hydrocarbons in the marine food web. Pp. 491-533 in Longhurst, A. (ed.): Analysis of Marine Ecosystems. Academic Press. New York.

Schneider, D. C. Hunt, Jr. G. L. \& Harrison, N. M. 1986: Mass and energy transfer to seabirds in the southeastern Bcring Sea. Cont. Shelf Res. 5, 241-258.
Smith, S. L. \& Lane. P. V. Z. 1988: Grazing of the spring diatom bloom in the New York Bight by the calanoid copepods Calanus finmarchicus, Metridia lucens and Centropages typicus. Cont. Shelf Res. 8, 485-509.

Smith, S. L. \& Vidal, J. 1984: Spatial and temporal effects of salinity, temperature and chlorophyll on the communities of zooplankton in the southeastern Bering Sea. J. Mar. Res. 42, 221-257.

Smith, S. L. \& Vidal, J. 1986: Variations in the distribution, abundance, and development of copepods in the southeastern Bering Sea in 1980 and 1981. Cont. Shelf Res. 5, 215-239.

Smith, S. L., Vidal, J. \& Lane, P. V. Z. 1982: PROBES: Processes and resources of the Bering Sea shelf, Zooplankton Data Report. Probes Data Report PDR 82-011. Inst. Mar. Sci., Univ. Alaska, Fairbanks. 480 pp.

Smith, S. L., Vidal, J. \& Lane, P. V. Z. 1983: PROBES: Processes and resources of the Bering Sea shelf, Zooplankton Data Report. Probes Data Report PDR 82-017. Inst. Mar. Sci., Univ. Alaska, Fairbanks. 600 pp.

Soboleva, M. S. 1974: Distribution and abundance of euphausiids in the autumn-winter period of 1971-1972 in the southern Barents Sea. Annales Biologiques 29, 40-41.

Soboleva, M. S. 1975: The distribution and abundance of euphausiids in the Barents Sea in autumn and winter 1972-1973. Annales Biologiques 30. 58-60.

Timofeyev, S. F. 1987: Habitats of eggs and early larvae of Barents Sea euphausiids. Oceanology 27, 237-238.

Vidal, J. \& Smith, S. L. 1986: Biomass, growth, and development of populations of herbivorous zooplankton in the southeastern Bering Sea during spring. Deep-Sea Res. 33 , 523-556.

Vidal, J. \& Whitledge, T. 1982: Rates of metabolism of planktonic crustaceans as related to body weight and temperature of habitat. J. Plankton Res. 4, 77-84.

Wiebe, P. H., Burt, K. H., Boyd, S. H. \& Morton, A. W. 1976: A multiple opening/closing net and environmental sensing system for sampling zooplankton. J. Mar. Res. 34, 313-326.

Zelikman, E. A.. Lukashevich, 1. P. \& Drobysheva. S. S. 1978: Aggregative distribution of Thysanoessa inermis (Krøyer) and T. raschi (M. Sars) (Euphausiacea) in the Barents Sea. Oceanology 18, 709-713.

Zelikman, E. A., Lukashevich, I. P., Drobysheva, S. S. \& Degtereva, A. A. 1980: Fluctuations in the number of eggs of the Barents Sea crustaceans Thysanoessa inermis $\mathrm{Kr}$. and T. raschii (M. Sars) (Euphausiacea). Oceanology 20,716-721 